Check for updates

Cite this: RSC Adv., 2018, 8, 40866

\title{
High-performance yttrium-iron alloy doped Pt-free catalysts on graphene for hydrogen evolution
}

\begin{abstract}
Pengcheng Zhu, (D) abc Dandan Lyu ${ }^{\text {abc }}$ and Pei Kang Shen*abc
Research into the preparation and application of metal/graphene nanocomposite materials is an important issue in the field of graphene applications. Metal nanomaterials and graphene materials have many excellent properties and have been perfectly combined into metal/graphene nanocomposite materials. These offer the high catalytic activity of metal nanomaterials and the high specific surface area and favorable electrical conductivity of graphene. The unique advantages can produce synergistic effects and can significantly improve the overall performance of the composite materials. This gives the metal/graphene nanocomposite materials excellent application prospects for hydrogen evolution. Here, we report the preparation of yttrium-doped palladium/iron on graphene $\left(\mathrm{Pd} / \mathrm{YFeO}_{3} /{ }^{G} \mathrm{C}\right)$ using a simple and efficient method. The catalytic performance of the $\mathrm{Pd} / \mathrm{YFeO}_{3} /{ }^{\mathrm{G}} \mathrm{C}$ nanocomposites for water electrolysis and hydrogen production was evaluated. The results show that the overpotential for the hydrogen evolution reaction at $-10 \mathrm{~mA} \mathrm{~cm}{ }^{-2}$ is only $15 \mathrm{mV}$, which is competitive with $\mathrm{Pt} / \mathrm{C}$ catalysts. The $\mathrm{Pd} / \mathrm{YFeO}_{3} /{ }^{\mathrm{G}} \mathrm{C}$ is highly active for hydrogen evolution with an onset potential of $-8 \mathrm{mV}$ in $0.5 \mathrm{M} \mathrm{H}_{2} \mathrm{SO}_{4}$ solution and a Tafel slope of $37 \mathrm{mV} \mathrm{dec}^{-1}$ with a Pd loading of only $20 \mu \mathrm{g}_{\mathrm{Pd}} \mathrm{cm}^{-2}$. These results clearly demonstrated that $\mathrm{Pd} / \mathrm{YFeO}_{3} /{ }^{\mathrm{G}} \mathrm{C}$ is an excellent catalyst for hydrogen evolution.
\end{abstract}

Received 28th October 2018 Accepted 29th November 2018

DOI: $10.1039 / \mathrm{c} 8 \mathrm{ra08922a}$

rsc.li/rsc-advances more economical non-precious metal materials such as $\mathrm{Ni}$, Mo, W, and other transition-metal-based electrocatalysts. ${ }^{9-15}$ However, compared with precious metals, the catalytic performance of non-precious metals is not good enough. Precious metal catalysts offer high catalytic performance, low overpotential, and good stability, but they also have a low utilization rate (less than $20 \%$ of the Pt catalyst is used), ${ }^{\mathbf{1 6 , 1 7}}$ Precious metals are also expensive and rare, making the bulk preparation of precious metal catalysts challenging. Therefore, research into low-cost and high-efficiency non-precious metal catalysts is an active research topic, despite their lower performance. While the hydrogen evolution performance of non-precious metal catalysts is similar to platinum when placed on carbon, ${ }^{\mathbf{1 2 , 1 4 , 1 8 - 2 0}}$ the catalyst preparation process is cumbersome and complicated by poor reproducibility.

Here, using the features of successful catalysts, we prepared a palladium catalyst prepared from rare earth elements and graphene (Pd is cheaper than $\mathrm{Pt}$ ). We doped palladium into iron and yttrium on a graphene catalyst $\left(\mathrm{Pd} / \mathrm{YFeO}_{3} /{ }^{\mathrm{G}} \mathrm{C}\right)$ for hydrogen evolution. Compared with non-precious metals, the preparation of Pd catalyst is simple and reproducible. The results show that the overpotential of the HER at $-10 \mathrm{~mA} \mathrm{~cm}{ }^{-2}$ is only $15 \mathrm{mV}$, which is can competitive with the $\mathrm{Pt} / \mathrm{C}$ catalyst. The $\mathrm{Pd} /$ $\mathrm{YFeO}_{3} /{ }^{\mathrm{G}} \mathrm{C}$ is highly active for HER with am onset potential of $-8 \mathrm{mV}$ in $0.5 \mathrm{M} \mathrm{H}_{2} \mathrm{SO}_{4}$, the Tafel slope is $37 \mathrm{mV} \mathrm{dec}^{-1}$ at a Pdloading of only $20 \mu \mathrm{g}_{\mathrm{Pd}} \mathrm{cm}^{-2}$. These results clearly demonstrated that $\mathrm{Pd} / \mathrm{YFeO}_{3} /{ }^{\mathrm{G}} \mathrm{C}$ is an excellent catalyst for hydrogen evolution.
${ }^{a}$ Collaborative Innovation Center of Sustainable Energy Materials, Guangxi University, Nanning, 530004, P. R. China

${ }^{b}$ Guangxi Key Laboratory of Electrochemical Energy Materials, Guangxi University, Nanning, 530004, P. R. China

${ }^{c}$ State Key Laboratory of Processing for Non-ferrous Metal and Featured Materials, Guangxi University, Nanning, 530004, P. R. China. E-mail: pkshen@gxu.edu.cn 


\section{Experimental}

\subsection{Materials}

Palladium chloride $99.0 \%\left(\mathrm{PdCl}_{2}\right)$, iron(III) chloride hexahydrate 99.0\% $\left(\mathrm{FeCl}_{3} \cdot 6 \mathrm{H}_{2} \mathrm{O}\right)$, yttrium(III) nitrate hexahydrate $99.5 \%$ and potassium hydroxide $85.0 \%(\mathrm{KOH})$ were provided by Guangdong Guanghua Sci-Tech Co., Ltd. Graphene were provided by Collaborative Innovation Center of Renewable Energy Materials in Guangxi University.

\subsection{Catalyst preparation}

The graphene was pretreated in $\mathrm{HNO}_{3}(3 \mathrm{M})$ with stirring for $2 \mathrm{~h}$ followed by addition of $\mathrm{H}_{2} \mathrm{SO}_{4}$. The samples were continually stirred and heated at $80{ }^{\circ} \mathrm{C}$ for $6 \mathrm{~h}$ in an oil bath. Finally, the solution was filtered using a microfiltration membrane (diameter $50 \mathrm{~mm}$, microporosity $0.5 \mu \mathrm{m}$ ) and washed many times with deionized water. This was then dried at $50{ }^{\circ} \mathrm{C}$ for $6 \mathrm{~h}$ in a vacuum oven.

A liquid metal reduction method was used to prepare catalyst nanocomposite materials. First, $0.2 \mathrm{~g}$ of pretreated graphene was dispersed in dimethylformamide and ultrasonicated for $6 \mathrm{~h}$ in an ultrasonic bath (HN-500A). The $0.12 \mathrm{~g}$ of $\mathrm{YN}_{3} \mathrm{O}_{9}$ $\cdot 6 \mathrm{H}_{2} \mathrm{O}$ and $0.08 \mathrm{~g}$ of $\mathrm{FeCl}_{3} \cdot 6 \mathrm{H}_{2} \mathrm{O}$ were dissolved in $25 \mathrm{~mL}$ deionized water and added to the dispersed graphene followed by ultrasonication for $6 \mathrm{~h}$. Finally, $2.2 \mathrm{~mL}$ of dissolved $\mathrm{PdCl}_{2}$ $\left(10 \mathrm{mg} \mathrm{mL}^{-1}\right)$ was added dropwise to the mixed solution and continually ultrasonicated for $6 \mathrm{~h}$; the solution was filtered using a microfiltration membrane (diameter $50 \mathrm{~mm}$, microporosity $0.5 \mu \mathrm{m})$. This was washed several times with deionized water and then dried at $50{ }^{\circ} \mathrm{C}$ for $6 \mathrm{~h}$ in a vacuum oven. After grinding, the powders were calcined at $800{ }^{\circ} \mathrm{C}$ for $2 \mathrm{~h}$ in a tube furnace under a pure nitrogen flow.

\subsection{Catalyst characterization}

The Raman spectra were obtained by a Raman spectrometer (Horiba, LabRAM HR Evolution) using a TE air-cooled $576 \times$ 400 CCD array in a confocal Raman system with a laser wavelength of $532 \mathrm{~nm}$. An X-ray diffractometer (XRD, SmartLab) with $\mathrm{Cu}-\mathrm{K} \alpha$ radiation was used for catalyst structure analysis from $10^{\circ}$ to $90^{\circ}$. Scanning electron microscopy (SEM, SU8220) and transmission electron microscopy (TEM, Titan ETEM G2 80300) were used to study the catalyst morphology and calculate the size and lattice parameters of the precious metals and metal oxide particles. The Brunauer-Emmett-Teller (BET, ASAP 2460)

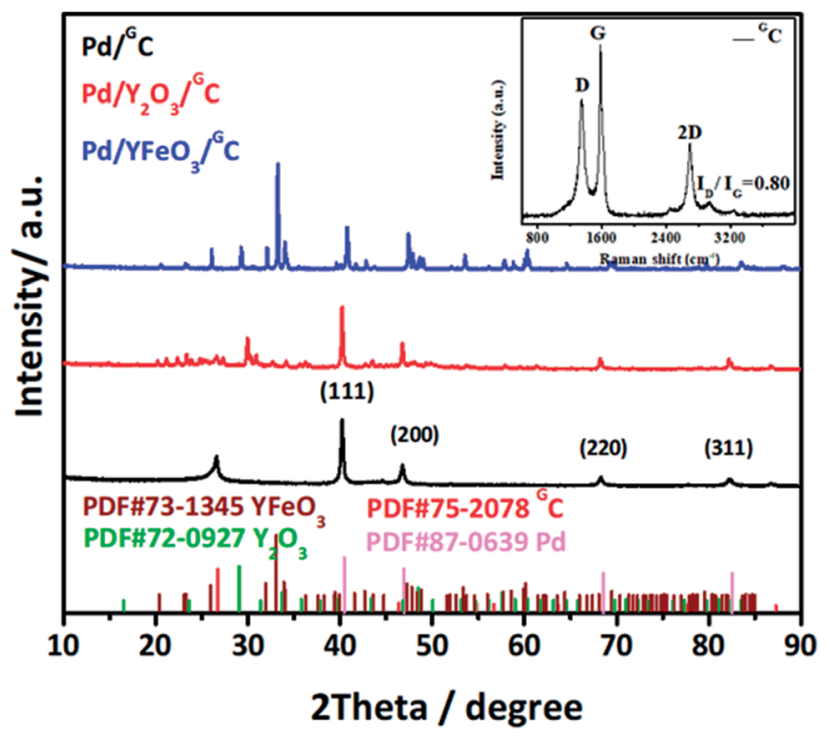

Fig. 1 XRD patterns of $\mathrm{Pd} /{ }^{\mathrm{G}} \mathrm{C}, \mathrm{Pd} / \mathrm{Y}_{2} \mathrm{O}_{3} /{ }^{\mathrm{G}} \mathrm{C}$ and $\mathrm{Pd} / \mathrm{YFeO}_{3} /{ }^{\mathrm{G}} \mathrm{C}$.

method was used to measure the surface area of the catalyst. Xray photoelectron spectroscopy (XPS, Kratos Axis Ultra-DLD) with $1486.6 \mathrm{eV} \mathrm{Al-K} \alpha$ as an excitation source was used to analyze the chemical composition and elemental chemical binding of the samples.

\subsection{Electrochemical characterization}

Electrochemical characterization used cyclic voltammetry (CV) and linear sweep voltammetry (LSV). These were performed with a potentiostat and a rotating ring disk electrode (RRDE) system (PINE) in a conventional three-electrode cell. The test system contained a carbon electrode as the counter electrode, a reversible hydrogen electrode (RHE) as the reference electrode, and a rotating disk electrode as the working electrode. The catalyst ink was prepared via ultrasonic blending (30 min) of $5 \mathrm{mg} \mathrm{Pd} / \mathrm{YFeO}_{3} /{ }^{\mathrm{G}} \mathrm{C}$ in a solution containing $0.09 \mathrm{~mL}$ of $\mathrm{H}_{2} \mathrm{O}$, $0.4 \mathrm{~mL}$ of ethanol, and $0.01 \mathrm{~mL}$ of $5 \mathrm{wt} \%$ Nafion to obtain a uniform ink. The $10 \mu \mathrm{L}$ of well-dispersed ink was carefully dropped on the rotating disk electrode surface, and the Pd loading is only $20 \mu \mathrm{g}_{\mathrm{Pd}} \mathrm{cm}^{-2}$. This ink was dried naturally for over $30 \mathrm{~min}$ for subsequent electrochemical testing. To evaluate the HER activity, CV curves were created from 0 to $1.1 \mathrm{~V}$ with a scan rate of $50 \mathrm{mV} \mathrm{s}^{-1}$ in a $0.5 \mathrm{M} \mathrm{H}_{2} \mathrm{SO}_{4}$ solution saturated with $\mathrm{N}_{2}$. The rotating disk electrode (RDE) measurements were
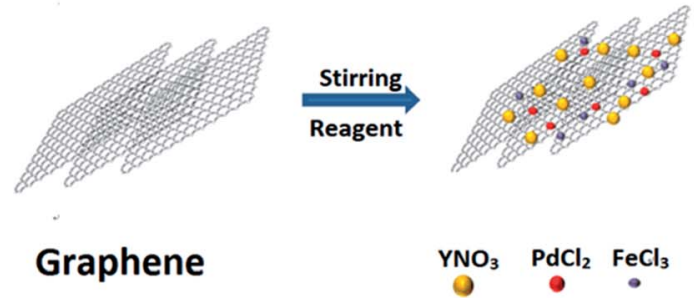

$\begin{array}{lll}\mathrm{YNO}_{3} & \mathrm{PdCl}_{2} & \mathrm{FeCl}_{3}\end{array}$
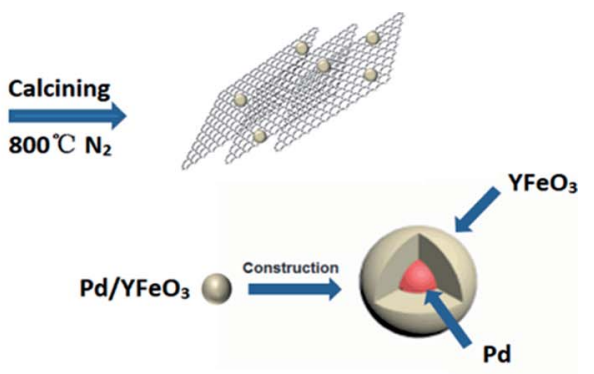

Scheme 1 Schematic formation of the $\mathrm{Pd} / \mathrm{YFeO}_{3} /{ }^{\mathrm{G}} \mathrm{C}$ composite. 

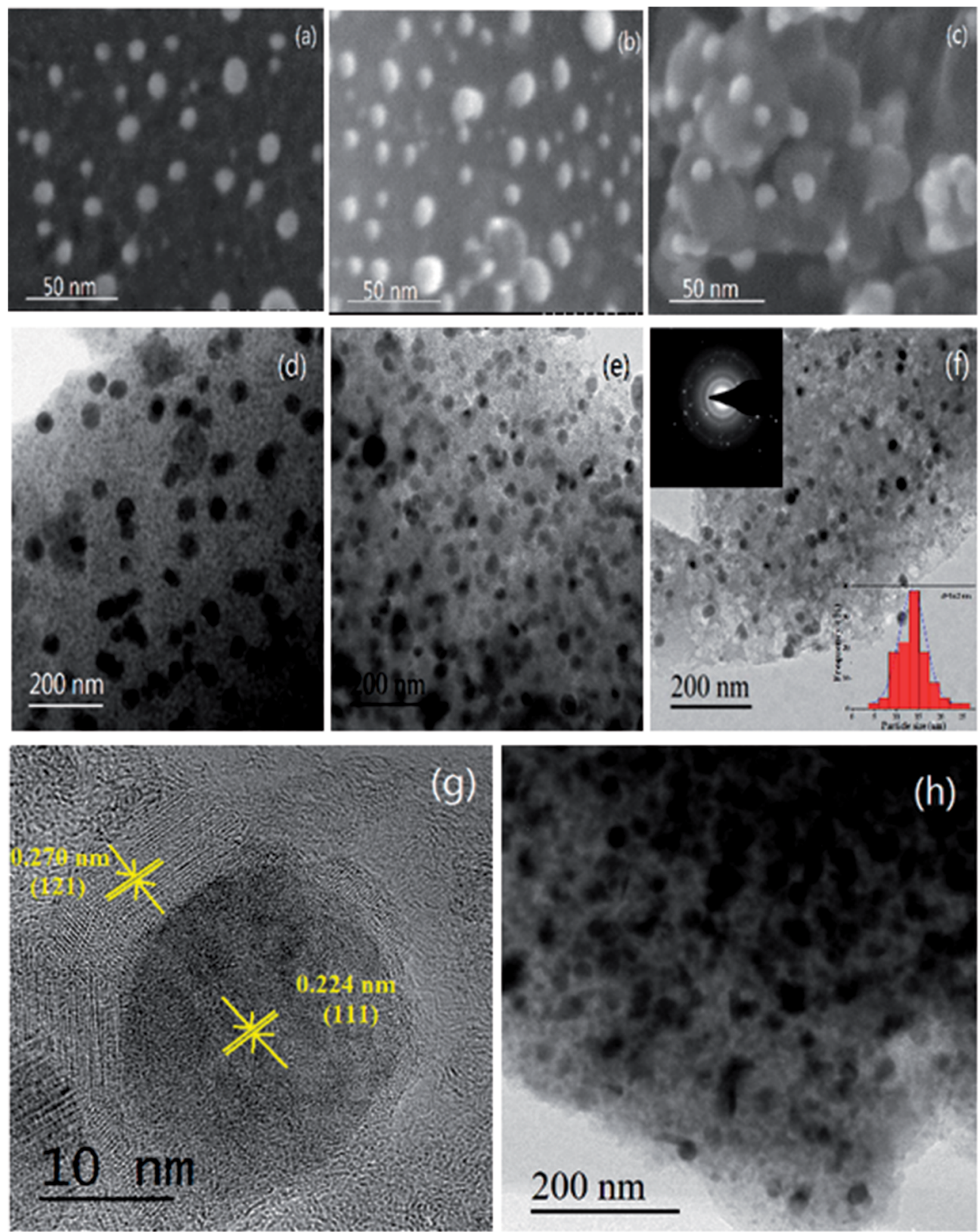

Fig. 2 The SEM images of $\mathrm{Pd} /{ }^{\mathrm{G}} \mathrm{C}, \mathrm{Pd} / \mathrm{Y}_{2} \mathrm{O}_{3} /{ }^{\mathrm{G}} \mathrm{C}$ and $\mathrm{Pd} / \mathrm{YFeO}_{3} /{ }^{\mathrm{G}} \mathrm{C}$ are shown in (a), (b) and (c) and the $\mathrm{TEM}$ images of $\mathrm{Pd} /{ }^{\mathrm{G}} \mathrm{C}, \mathrm{Pd} / \mathrm{Y}_{2} \mathrm{O}_{3} /{ }^{\mathrm{G}} \mathrm{C}$ and $\mathrm{Pd} /$ $\mathrm{YFeO}_{3} /{ }^{\mathrm{G}} \mathrm{C}$ are shown in (d), (e) and (f). (g) HRTEM image of a part of the Pd/YFeO $3 /{ }^{G} \mathrm{C}$ in (f). (h) The TEM image of Pd/YFeO $/ 3 /{ }^{G} \mathrm{C}$ after $8000 \mathrm{cycles}$ in $0.5 \mathrm{M} \mathrm{H}_{2} \mathrm{SO}_{4}$ aqueous solution at a scan rate of $10 \mathrm{mV} \mathrm{s}^{-1}$.

performed to obtain the LSV curves with a scan rate of $5 \mathrm{mV} \mathrm{s}^{-1}$ at a rotating speed of $1400 \mathrm{rpm}$ in a $\mathrm{N}_{2}$-saturated solution. The HER durability tests used $\mathrm{CV}$ and the circulation responses at a potential of -0.1 to $0.1 \mathrm{~V}$ with a $\mathrm{N}_{2}$-saturated $0.5 \mathrm{M} \mathrm{H}_{2} \mathrm{SO}_{4}$ electrolyte with 8000 circulations. For comparison, a commercial $\mathrm{Pt} / \mathrm{C}$ catalyst was also measured under the same conditions.

The Tafel slope was modeled by the empirical Tafel equation:

$$
\eta=a+b \times \log |j|
$$

Here, $\eta$ is the overpotential, $j$ is the measured current density, $b$ is the Tafel slope, and $a$ is a constant.

\section{Results and discussion}

The synthesis of the well-defined $\mathrm{Pd} / \mathrm{YFeO}_{3} /{ }^{\mathrm{G}} \mathrm{C}$ composite structure is realized via a pseudomorphic transformation of $\mathrm{Pd} / \mathrm{YFeO}_{3}$, as shown in Scheme 1 . To efficiently reveal the defect level and the degree of graphitization of carbon supporter materials, Raman spectroscopy (Fig. 1) was conducted for the graphene. It displayed three Raman peaks located at $\sim 1,350, \sim 1591$ and $\sim 2694 \mathrm{~cm}^{-1}$, corresponding to the $\mathrm{D}, \mathrm{G}$ and $2 \mathrm{D}$ bands, respectively. The D-band, also known as $\mathrm{sp}^{3}$ hybridized $\mathrm{C}$ atoms, indicates the level of defects or disorders in the carbon structure whereas the G-band reflects 

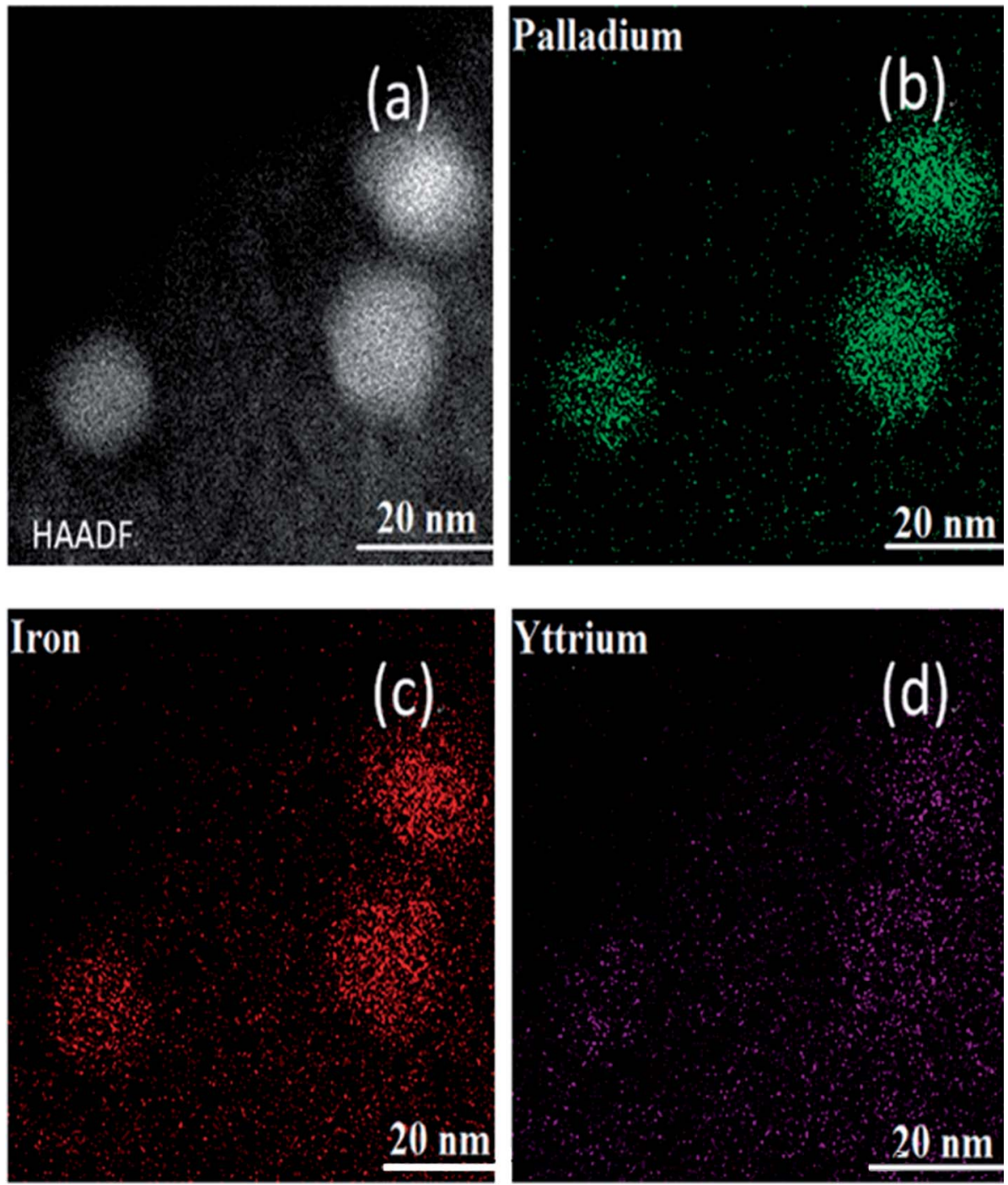

Fig. 3 (a-d) STEM-HAADF image and element mapping images of the $\mathrm{Pd} / \mathrm{YFeO}_{3} /{ }^{\mathrm{G}} \mathrm{C}$ composite.

the in-plane stretching vibration of $\mathrm{sp}^{2}$ hybridized $\mathrm{C}$ atoms. ${ }^{21}$ Moreover, the strong (normally about 1.0) D-band to G-band ratio $\left(I_{\mathrm{D}} / I_{\mathrm{G}}\right)$ suggests the high level of defects in the graphene. ${ }^{22,23}$ The $I_{\mathrm{D}} / I_{\mathrm{G}}$ ratio of graphene was calculated to 0.80 which illustrate high level of defects in the graphitic structure. Moreover, the second-order band is narrow and
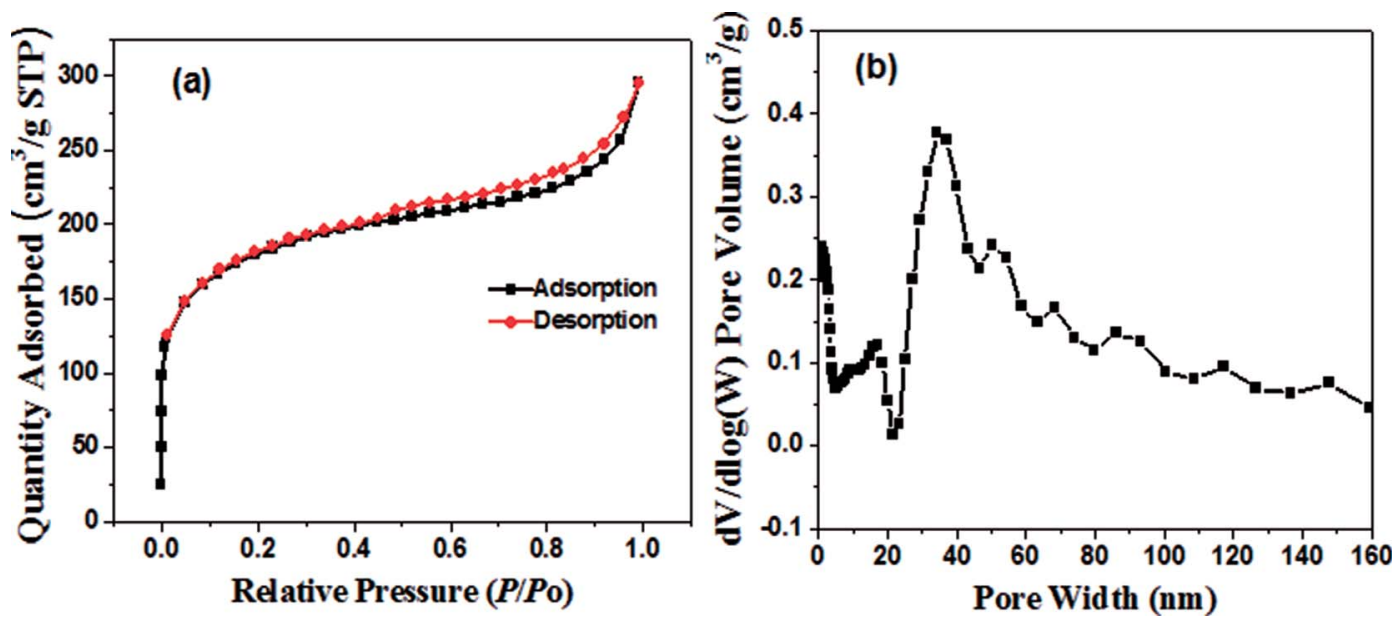

Fig. 4 (a) Nitrogen adsorption/desorption isotherm of $\mathrm{Pd} / \mathrm{YFeO}_{3} /{ }^{\mathrm{G}} \mathrm{C}$ and (b) DFT pore size distribution of $\mathrm{Pd} / \mathrm{YFeO} /{ }^{\mathrm{G}} \mathrm{C}$. 

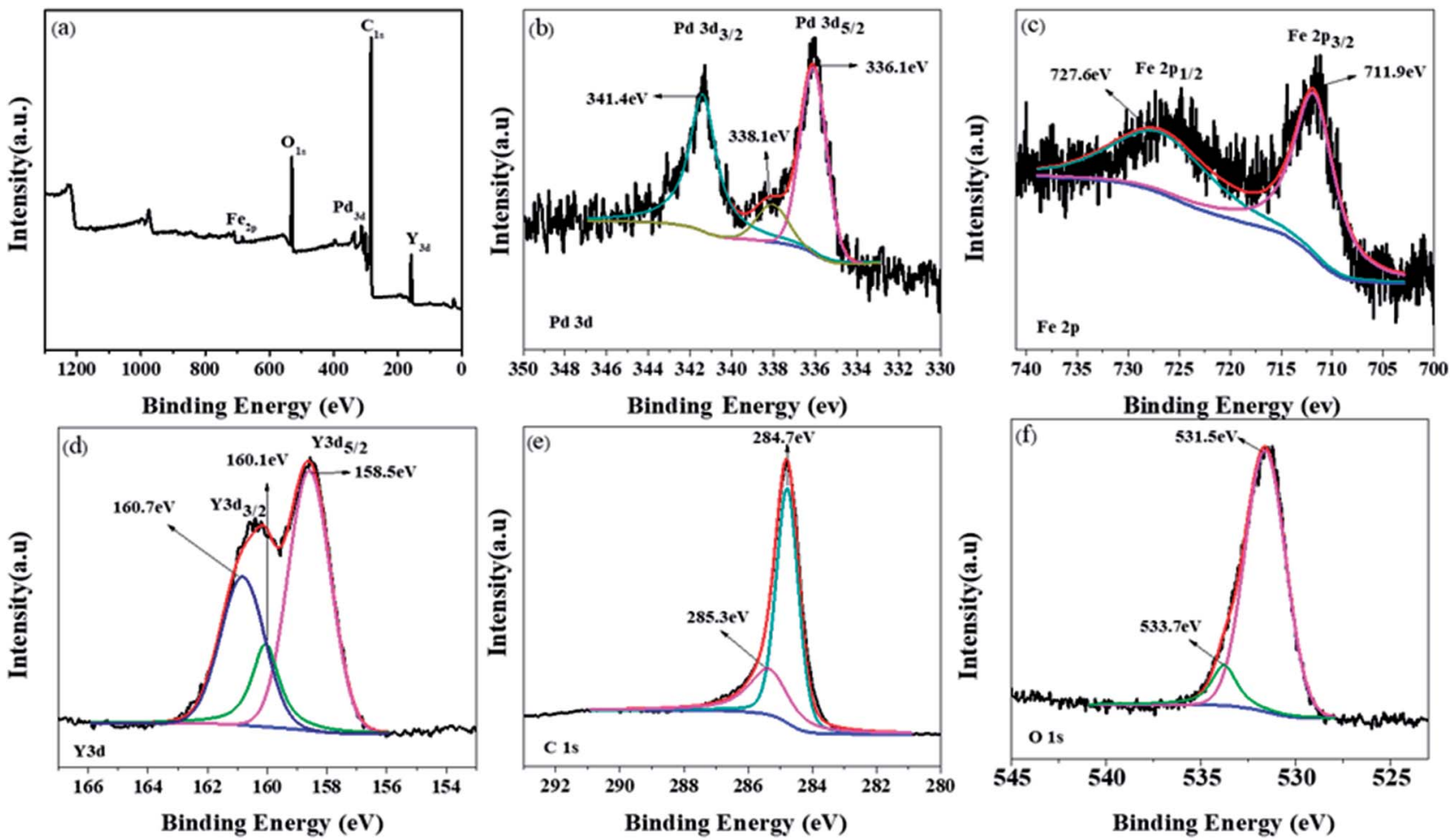

Fig. 5 (a) $\mathrm{Pd} / \mathrm{YFeO}_{3} /{ }^{\mathrm{G}} \mathrm{C}$ XPS spectrum, (b), (c), (d), (e) and (f) are $\mathrm{Pd}, \mathrm{Fe}, \mathrm{Y}, \mathrm{C}$ and $\mathrm{O}$ respectively.

strong, implying that the carbon is thin graphene with several layers. $^{24}$ Then XRD was used to study the crystallization properties of the samples. Fig. 1 shows the X-ray diffraction patterns of $\mathrm{Pd} /{ }^{\mathrm{G}} \mathrm{C}, \mathrm{Pd} / \mathrm{Y}_{2} \mathrm{O}_{3} /{ }^{\mathrm{G}} \mathrm{C}$, and $\mathrm{Pd} / \mathrm{YFeO}_{3} /{ }^{\mathrm{G}} \mathrm{C}$. There have same strong peak, the $2 \theta$ values of $40.11^{\circ}, 46.65^{\circ}, 68.11^{\circ}$ and $82.09^{\circ}$ were assigned to the (111), (200), (220) and (311) diffraction peaks of Pd (PDF\#87-0639), respectively. The data show that the crystalline Pd has a face-centered cubic (fcc) orientation. The $2 \theta$ of $33.12^{\circ}$ (121), $33.91^{\circ}$ (002), and $47.29^{\circ}$ (202) (Fig. 1) are characteristic of the lattice diffraction of $\mathrm{YFeO}_{3}(\mathrm{PDF} 773-1345)$. The $2 \theta$ of $29.13^{\circ}$ (222), $33.77^{\circ}$ (400), and $48.50^{\circ}(440)$ are characteristic of the lattice diffractions of $\mathrm{Y}_{2} \mathrm{O}_{3}$ (PDF\#72-0927). The diffraction peak near $26.6^{\circ}$ is the (111) lattice plane of graphene. The diffraction peak of $\mathrm{Pd} / \mathrm{Y}_{2} \mathrm{O}_{3} /{ }^{\mathrm{G}} \mathrm{C}$ at $26.6^{\circ}$ is not obvious, which indicates that the $\mathrm{Y}_{2} \mathrm{O}_{3}$ reduced the graphene's crystallinity. However, the diffraction peak of graphene in $\mathrm{Pd} / \mathrm{YFeO}_{3} /{ }^{\mathrm{G}} \mathrm{C}$ is unaffected.

The SEM images of $\mathrm{Pd} /{ }^{6} \mathrm{C}, \mathrm{Pd} / \mathrm{Y}_{2} \mathrm{O}_{3} /{ }^{\mathrm{G}} \mathrm{C}$ and $\mathrm{Pd} / \mathrm{YFeO}_{3} /{ }^{6} \mathrm{C}$ composite are shown in Fig. 2a-c. In Fig. 2c, the graphene was uniformly decorated on the $\mathrm{Pd} / \mathrm{YFeO}_{3}$ nanoparticles. The TEM images of $\mathrm{Pd} /{ }^{\mathrm{G}} \mathrm{C}, \mathrm{Pd} / \mathrm{Y}_{2} \mathrm{O}_{3} /{ }^{6} \mathrm{C}$ and $\mathrm{Pd} / \mathrm{YFeO}_{3} /{ }^{\mathrm{G}} \mathrm{C}$ composite are shown in Fig. $2 \mathrm{~d}-\mathrm{f}$. Fig. $2 \mathrm{f}$ shows a TEM image of the $\mathrm{Pd} /$ $\mathrm{YFeO}_{3} /{ }^{\mathrm{G}} \mathrm{C}$ composite. Metal particles are uniformly deposited on the graphene. The average particle size is estimated to be $14.2 \mathrm{~nm}$ for the $\mathrm{Pd} / \mathrm{YFeO}_{3} /{ }^{\mathrm{G}} \mathrm{C}$ based on the measurement of 100 particles in random regions. Fig. $2 \mathrm{~g}$ shows that the lattice spacing is $0.270 \mathrm{~nm}$, which corresponds to the (121) plane of $\mathrm{YFeO}_{3}$; the lattice spacing of $0.244 \mathrm{~nm}$ corresponds to the (111) plane of Pd, which is consistent with the XRD results. Fig. $2 \mathrm{~g}$ indicates that $\mathrm{Pd}$ is wrapped by $\mathrm{YFeO}_{3}$ alloy. This alloy layer is very thin, which can improve the performance and stability of Pd in $0.5 \mathrm{M} \mathrm{H}_{2} \mathrm{SO}_{4}$. Fig. $2 \mathrm{~h}$ shows that the TEM image of Pd/ $\mathrm{YFeO}_{3} /{ }^{\mathrm{G}} \mathrm{C}$ after 8000 cycles in $0.5 \mathrm{M} \mathrm{H}_{2} \mathrm{SO}_{4}$ aqueous solution at a scan rate of $10 \mathrm{mV} \mathrm{s}^{-1}$. From the TEM image, it was found that the metal particles in $\mathrm{Pd} / \mathrm{YFeO}_{3} /{ }^{\mathrm{G}} \mathrm{C}$ were uniformly dispersed and unchanged on the graphene. This means the $\mathrm{Pd} / \mathrm{YFeO}_{3} /{ }^{6} \mathrm{C}$ is very stable in $0.5 \mathrm{M} \mathrm{H}_{2} \mathrm{SO}_{4}$ aqueous solution. Fig. $3 \mathrm{a}-\mathrm{d}$ further confirms the sample elements and distribution. The Pd, Fe, and $\mathrm{Y}$ mapping of $\mathrm{Pd} / \mathrm{YFeO}_{3} /{ }^{6} \mathrm{C}$ clearly shows that the elements are distributed evenly on the graphene; Pd is encapsulated by the $\mathrm{YFeO}_{3}$ alloy. The distribution of the elements is clearly shown in the mapping. $\mathrm{Pd} / \mathrm{YFeO}_{3} /{ }^{\mathrm{G}} \mathrm{C}$ samples were obtained via nitrogen adsorption/desorption measurements (Fig. 4a). The hysteresis curves between $0-1.0 p / p_{0}$ are obviously type IV indicating that there is a large number of ordered micropores and mesopores in the catalyst material due to the layered structure. ${ }^{25}$ The BET surface area of $\mathrm{Pd} / \mathrm{YFeO}_{3} /{ }^{\mathrm{G}} \mathrm{C}$ approaches $439 \mathrm{~m}^{2} \mathrm{~g}^{-1}$, which illustrates the benefits of using graphene-it can give the sample a larger specific surface area to increase the sample's conductivity and electron mobility. The $\mathrm{BJH}$ analysis showed that the $\mathrm{Pd} / \mathrm{YFeO}_{3} /{ }^{\mathrm{G}} \mathrm{C}$ has a pore volume of $0.3124 \mathrm{~cm}^{3} \mathrm{~g}^{-1}$ and with a non-homogenous pore size distribution (Fig. 4b). The non-uniform pore size distribution may be due to particle aggregation in the catalyst. The $\mathrm{BJH}$ adsorption average pore width $(4 V / A)$ was $6.3856 \mathrm{~nm}$, and the $\mathrm{BJH}$ adsorption average pore width $(4 \mathrm{~V} / \mathrm{A})$ was $6.3204 \mathrm{~nm}$. These data suggested that the catalyst is mainly mesoporous. These qualities have been widely recognized as beneficial for an ample electrode/electrolyte interface for ion or charge accumulation performance during the HER and OER processes. ${ }^{26}$ 

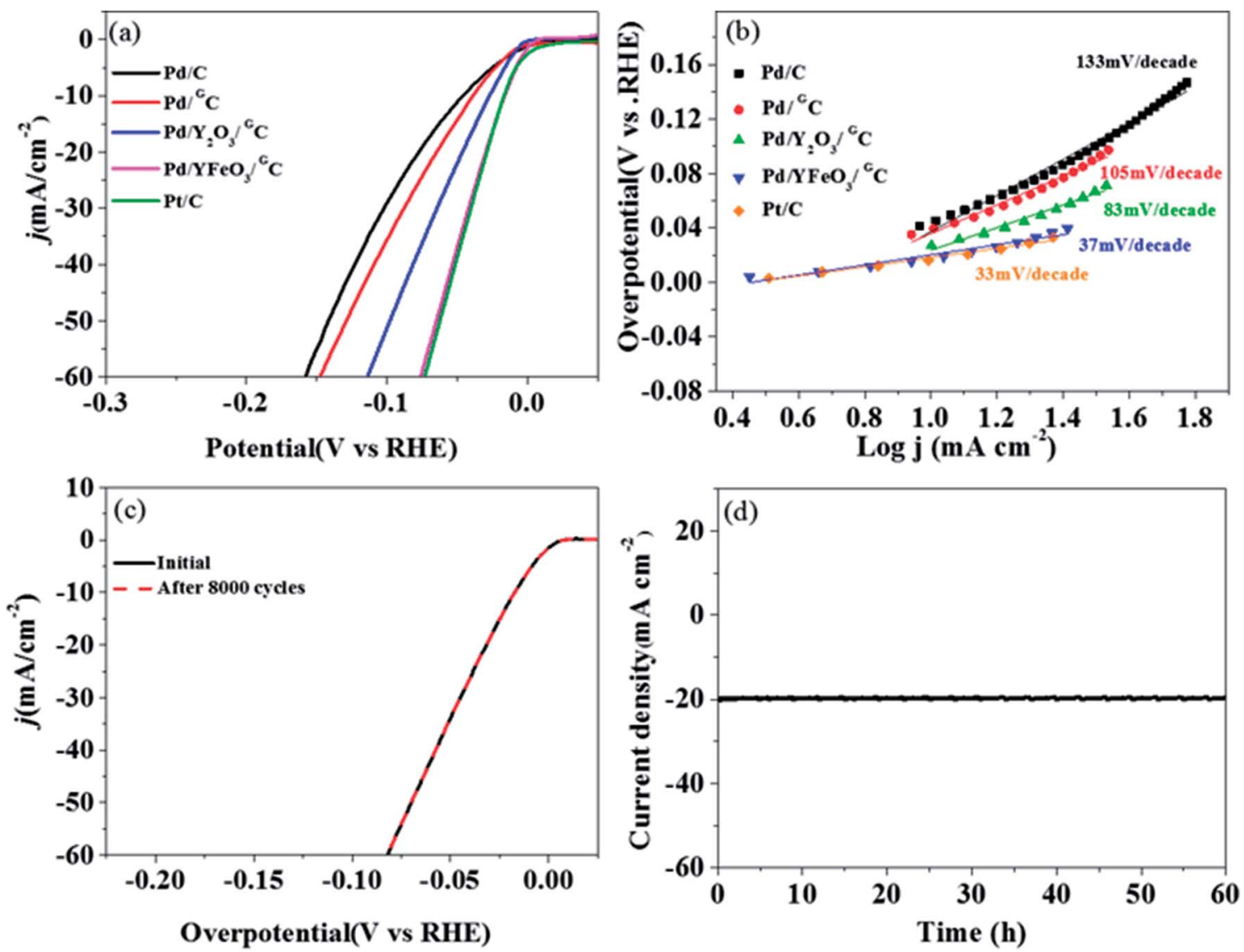

Fig. 6 (a) LSV curves of graphene or carbon powder modified with noble metals. (b) HER Tafel plots of Pd/C, Pd/ ${ }^{G} \mathrm{C}, \mathrm{Pd} / \mathrm{Y}_{2} \mathrm{O}_{3} /{ }^{G} \mathrm{C}, \mathrm{Pd} / \mathrm{YFeO}{ }_{3} /{ }^{\mathrm{G}} \mathrm{C}$ and $\mathrm{Pt} / \mathrm{C}$. (c) The stability polarization curve of $\mathrm{Pd} / \mathrm{YFeO}_{3} /{ }^{\mathrm{G}} \mathrm{C}$ before and after 8000 cycles in $0.5 \mathrm{M} \mathrm{H}_{2} \mathrm{SO}_{4}$ aqueous solution at a scan rate of $10 \mathrm{mV} \mathrm{s}^{-1}$ and (d) $\mathrm{Pd} / \mathrm{YFeO}_{3} /{ }^{\mathrm{G}} \mathrm{C}$ constant voltage stability diagram. All data were IR corrected.

Fig. 5a shows the binding configurations of different elements in $\mathrm{Pd} / \mathrm{YFeO}_{3} /{ }^{\mathrm{G}} \mathrm{C}$ via XPS. The presence of $\mathrm{Pd}, \mathrm{Fe}, \mathrm{Y}, \mathrm{C}$, and $\mathrm{O}$ was obvious in the survey spectrum of the $\mathrm{Pd} / \mathrm{YFeO}_{3} /{ }^{\mathrm{G}} \mathrm{C}$ nanocomposite system. Fig. 5b shows the XPS spectra and indicates the presence of surface Pd in the form of two peaks at $336.3 \mathrm{eV}$ and $341.5 \mathrm{eV}$. These were resolved for Pd $\left(2 \mathrm{p}_{5 / 2}\right)$ and Pd $\left(2 \mathrm{p}_{3 / 2}\right)^{27,28}$ confirming elemental Pd. The XPS spectra fitting processing of Fe is shown in Fig. $5 \mathrm{c}$. The peak at $727 \mathrm{eV}$ can be matched with $\mathrm{Fe}^{3+}$, and the peak at $712 \mathrm{eV}$ matches $\mathrm{Fe}^{2+}$. In Fig. 5d, the $\mathrm{Y} 3 \mathrm{~d}$ was observed at 157.9 and $159.8 \mathrm{eV}^{29,30}$ The two peaks of C (1s) at 284.7 and $285.3 \mathrm{eV}$ show two types of carbon. The peak at $284.7 \mathrm{eV}$ is involved in $\mathrm{C}-\mathrm{C}$ bonds, and the peak at $285.3 \mathrm{eV}$ is involved in $\mathrm{C}-\mathrm{N}$ bonds. ${ }^{\mathbf{3 1 , 3 2}}$

The HER activity of $\mathrm{Pd} / \mathrm{YFeO}_{3} /{ }^{\mathrm{G}} \mathrm{C}$ was investigated via electrochemical measurements in $0.5 \mathrm{M} \mathrm{H}_{2} \mathrm{SO}_{4}$. At a current density of $10 \mathrm{~mA} \mathrm{~cm}{ }^{-2}$, the $\mathrm{Pd} / \mathrm{YFeO}_{3} /{ }^{6} \mathrm{C}$ showed excellent low overpotential of $15 \mathrm{mV}$-this is the same as the overpotential of the $\mathrm{Pt} / \mathrm{C}$ and is lower than $\mathrm{Pd} / \mathrm{C}(43 \mathrm{mV}), \mathrm{Pd} /{ }^{\mathrm{G}} \mathrm{C}(37 \mathrm{mV})$, and $\mathrm{Pd} /$ $\mathrm{Y}_{2} \mathrm{O}_{3} /{ }^{\mathrm{G}} \mathrm{C}(26 \mathrm{mV})$ (Fig. 6a). In addition, $\mathrm{Pd} / \mathrm{YFeO}_{3} /{ }^{6} \mathrm{C}$ only needs potentials of about $-0.03 \mathrm{~V},-0.042 \mathrm{~V}$, and $-0.076 \mathrm{~V}$ to reach current densities of 20,30 and $60 \mathrm{~mA} \mathrm{~cm}{ }^{-2}$, respectively. The HER activity of $\mathrm{Pd} / \mathrm{YFeO}_{3} /{ }^{\mathrm{G}} \mathrm{C}$ is the best in all the as-prepared catalysts because of the reduction of $\mathrm{Pd}-\mathrm{H}$ binding energy, which is due to the Pd lattice parameter compressed with the addition of $\mathrm{YFeO}_{3}$ and the improvement of the electrical conductivity of palladium by graphene. ${ }^{33}$. The Tafel plots of Pd/ $\mathrm{C}, \mathrm{Pd} /{ }^{6} \mathrm{C}, \mathrm{Pd} / \mathrm{Y}_{2} \mathrm{O}_{3} /{ }^{\mathrm{G}} \mathrm{C}$ and $\mathrm{Pd} / \mathrm{YFeO}_{3} /{ }^{\mathrm{G}} \mathrm{C}$ are shown in Fig. $6 \mathrm{~b}$. The Tafel slope of $\mathrm{Pd} / \mathrm{YFeO}_{3} /{ }^{\mathrm{G}} \mathrm{C}$ is $37 \mathrm{mV}$ per decade, which is lower than the other samples and is very close to the Tafel slope of $\mathrm{Pt} / \mathrm{C}$ ( $33 \mathrm{mV}$ per decade). To investigate the stability of $\mathrm{Pd} /$ $\mathrm{YFeO}_{3} /{ }^{\mathrm{G}} \mathrm{C}$ catalysts, we first assessed the circulation stability of $\mathrm{Pd} / \mathrm{YFeO}_{3} /{ }^{\mathrm{G}} \mathrm{C}$ following the accelerated durability test protocol by cycling the potential between $0.1 \mathrm{~V}$ and $-0.3 \mathrm{~V}$ at $100 \mathrm{mV} \mathrm{s}^{-1}$ for HER as represented in Fig. 6c. The LSV curves of Pd/ $\mathrm{YFeO}_{3} /{ }^{\mathrm{G}} \mathrm{C}$ had no change after 8000 cyclic voltammetry (CV) cycles versus baseline. This highlights the cycling stability of the sample and proves that the catalyst is very stable for HER. Then we conducted a chronoamperometry test for HER with the current density fixed at $20 \mathrm{~mA} \mathrm{~cm}{ }^{-2}$ with $1600 \mathrm{rpm}$ in $\mathrm{N}_{2}$-saturated $0.5 \mathrm{M} \mathrm{H}_{2} \mathrm{SO}_{4}$ solutions 60 hours shown in Fig. $6 \mathrm{~d}$. The test revealed that $\mathrm{Pd} / \mathrm{YFeO}_{3} /{ }^{6} \mathrm{C}$ catalysts' HER potentials remained very stable with increases of only $30 \mathrm{mV}$ after measured continuously $60 \mathrm{~h}$.

\section{Conclusions}

In conclusion, $\mathrm{Pd} / \mathrm{C}, \mathrm{Pd} /{ }^{\mathrm{G}} \mathrm{C}, \mathrm{Pd} / \mathrm{Y}_{2} \mathrm{O}_{3} /{ }^{\mathrm{G}} \mathrm{C}$, and $\mathrm{Pd} / \mathrm{YFeO}_{3} /{ }^{\mathrm{G}} \mathrm{C}$ catalysts were successfully synthesized. The HER activity of the $\mathrm{Pd} / \mathrm{YFeO}_{3} /{ }^{\mathrm{G}} \mathrm{C}$ composite is better than the other catalysts in $0.5 \mathrm{M} \mathrm{H}_{2} \mathrm{SO}_{4}$ solution. The activity of the $\mathrm{Pd} / \mathrm{YFeO}_{3} /{ }^{\mathrm{G}} \mathrm{C}$ 
composite for the HER is the same as commercial $\mathrm{Pt} / \mathrm{C}$ due to the porous multilayer structure of graphene and the HER activity of $\mathrm{YFeO}_{3}$. The $\mathrm{Pd} / \mathrm{YFeO}_{3} /{ }^{\mathrm{G}} \mathrm{C}$ composite exhibits a low overpotential, small Tafel slope, and robust HER durability. The $\mathrm{Pd} / \mathrm{YFeO}_{3} /{ }^{\mathrm{G}} \mathrm{C}$ composite is more easily prepared than other nonnoble metal catalysts, and it is the most promising energy storage material.

\section{Conflicts of interest}

There are no conflicts to declare.

\section{Acknowledgements}

This work was supported by the National Basic Research Program of China (2015CB932304), the Major International (Regional) Joint Research Project (51210002), the Natural Science Foundation of Guangdong Province (2015A030312007), the Guangxi Science and Technology Project (AB16380030), and the Danish Initiative Towards Non-precious Metal Polymer Fuel Cells (4106-000012B).

\section{References}

1 S. Chu and A. Majumdar, Nature, 2012, 488, 294-303.

2 J. O. M. Bockris, Int. J. Hydrogen Energy, 2003, 28, 131-133.

3 J. A. Turner, Science, 2004, 305, 972-974.

4 J. Kibsgaard and T. F. Jaramillo, Angew. Chem., Int. Ed., 2014, 53, 14433.

5 T. Ding, Z. Wang, L. Zhang, C. Wang, Y. Sun and Q. Yang, J. Mater. Chem. A, 2016, 4, 15309-15315.

6 M. Wu, P. K. Shen, Z. Wei, S. Song and M. Nie, J. Power Sources, 2007, 166, 310-316.

7 J. Lu, L. Zhang, S. Jing, L. Luo and S. Yin, Int. J. Hydrogen Energy, 2017, 42, 5993-5999.

8 H. Lv, X. Chen, D. Xu, Y. Hu, H. Zheng, S. L. Suib and B. Liu, Appl. Catal., B, 2018, 238, 525-532.

9 H. Du, Q. Liu, N. Cheng, A. M. Asiri, X. Sun and C. M. Li, J. Mater. Chem. A, 2014, 2, 14812-14816.

10 W. Zhou, D. Hou, Y. Sang, S. Yao, J. Zhou, G. Li, L. Li, H. Liu and S. Chen, J. Mater. Chem. A, 2014, 2, 11358-11364.

11 J. Jiang, C. Wang, J. Zhang, W. Wang, X. Zhou, B. Pan, K. Tang, J. Zuo and Q. Yang, J. Mater. Chem. A, 2015, 3, 499-503.

12 Y. Jin and P. K. Shen, J. Mater. Chem. A, 2015, 3, 2008020085.
13 L. Zhang, J. Mu, Z. Wang, G. Li, Y. Zhang and Y. He, J. Alloys Compd., 2016, 671, 60-65.

14 J. Yin, Q. Fan, Y. Li, F. Cheng, P. Zhou, P. Xi and S. Sun, J. Am. Chem. Soc., 2016, 138, 14546-14549.

15 J. Jin, Y. Zhu, Y. Liu, Y. Li, W. Peng, G. Zhang, F. Zhang and X. Fan, Int. J. Hydrogen Energy, 2017, 42, 3947-3954.

16 A. Bazylak, D. Sinton and N. Djilali, J. Power Sources, 2005, 143, 57-66.

17 F. Mathieu-Potvin and L. Gosselin, Int. J. Hydrogen Energy, 2014, 39, 7382-7401.

18 Y. Jin, H. Wang, J. Li, X. Yue, Y. Han, P. K. Shen and Y. Cui, Adv. Mater., 2016, 28, 3785-3790.

19 B. Hinnemann, P. G. Moses, J. Bonde, K. P. Jorgensen, J. H. Nielsen, S. Horch, I. Chorkendorff and J. K. Norskov, J. Am. Chem. Soc., 2005, 127, 5308-5309.

20 L. Chai, W. Yuan, X. Cui, H. Jiang, J. Tang and X. Guo, RSC Adv., 2018, 8, 26871-26879.

21 A. C. Ferrari, J. C. Meyer, V. Scardaci, C. Casiraghi, M. Lazzeri, F. Mauri, S. Piscanec, D. Jiang, K. S. Novoselov and S. Roth, Phys. Rev. Lett., 2006, 97, 187401.

22 Z. Jin, J. Yao, C. Kittrell and J. M. Tour, ACS Nano, 2011, 5, 4112.

23 A. C. Ferrari, Solid State Commun., 2007, 143, 47-57.

24 A. C. Ferrari and D. M. Basko, Nat. Nanotechnol., 2013, 8, 235-246.

25 Z.-Y. Wu, X.-X. Xu, B.-C. Hu, H.-W. Liang, Y. Lin, L.-F. Chen and S.-H. Yu, Angew. Chem., Int. Ed., 2015, 54, 8179-8183.

26 J. Hou, C. Cao, F. Idrees and X. Ma, ACS Nano, 2015, 9, 25562564.

27 T. Bhowmik, M. K. Kundu and S. Barman, ACS Catal., 2016, 6, 1929-1941.

28 K. Qi, S. Yu, Q. Wang, W. Zhang, J. Fan, W. Zheng and X. Cui, J. Mater. Chem. A, 2016, 4, 4025-4031.

29 M. H. Seo, S. M. Choi, J. K. Seo, S. H. Noh, W. B. Kim and B. Han, Appl. Catal., B, 2013, 129, 163-171.

30 X. Liu, E. H. Yu and K. Scott, Appl. Catal., B, 2015, 162, 593601.

31 L. Tao, Q. Wang, S. Dou, Z. Ma, J. Huo, S. Wang and L. Dai, Chem. Commun., 2016, 52, 2764-2767.

32 T. Cheng and Z. Qiang, Adv. Mater., 2017, 29, 1604103.

33 N. Danilovic, R. Subbaraman, D. Strmcnik, V. R. Stamenkovic and N. M. Markovic, J. Serb. Chem. Soc., 2013, 78, 2007-2015. 